\title{
Agent Given Within 30 Days
}

National Cancer Institute

\section{Source}

National Cancer Institute. Agent Given Within 30 Days. NCI Thesaurus. Code C54063.

Administration of an agent within 30 days of a specified date. 